\title{
Comparative Analysis of COVID-19 Vaccines
}

\author{
Hassan Naji
}

\section{ABSTRACT}

\begin{abstract}
SARS-CoV-2 is the cause of the recent outbreak of COVID-19. This outbreak has resulted in many infected individuals worldwide. The unavailability of a specific antiviral treatment caused many individuals to lose their lives due to COVID-19. The rising number of deaths and rapidly spreading infection demand the development of an effective vaccine against the virus. Many researchers and companies across the globe have started attempts to create effective vaccine that can provide quick and long-lasting protection against SARS-CoV-2. These vaccines employ different forms of constituents that ultimately stimulate the immune response to produce neutralizing antibodies in an individual. Among these vaccines are AZD1222, BNT162b2, and mRNA-1273.
\end{abstract}

Keywords: 2019-nCoV, SARS-CoV-2, Coronavirus, Novel Coronavirus, AZD1222, BNT162b2, mRNA-1273, Pfizer, Moderna, Oxford University, Spike (S) glycoproteins, ACE2 Receptors.
Published Online: February 4, 2021

ISSN: $2593-8339$

DOI: 10.24018 /ejmed.2021.3.1.642

\section{Hassan Naji*}

Purdue University Northwest, USA

(e-mail: hnaji@ pnw.edu)

*Corresponding Author

\section{INTRODUCTION}

Since the past twenty years, SARS-CoV-2 is the third novel beta-coronavirus of its kind that is highly infectious and easily transmitted from person to person. Until now, more than 30 million individuals have been infected with SARS-CoV-2 around the globe [1]. According to World Health Organization [2] the pandemic has resulted worldwide in 79 million reported cases with 1.7 million deaths as of December 30, 2020. The genome of SARSCoV-2 is closely related to that of RaTG13 and RmYN02 viruses found in Rhinolophus affinis and Rhinolophus malayanus, respectively. It is believed that SARS-CoV-2 is originated in bats [3].

The clinical syndrome caused by SARS-CoV-2 is referred as coronavirus disease-19 (COVID-19) which can present with gastrointestinal disease, hyperinflammatory syndrome, cardiac pathology and coagulopathy, most often resulting in cardiac failure. Fatalities are most commonly associated with advanced age, co-morbid conditions like hypertension, obesity and diabetes, and immunocompromised state of the patients infected with SARS-CoV-2. SARS-CoV-2 enters the host cells via the fusion of viral transmembrane homotrimeric spike (S) glycoproteins with the ACE2 (angiotensin-converting enzyme 2) receptors. As soon as the genomic sequence of SARS-CoV-2 is revealed, efforts have been started to develop vaccine candidates mainly targeting the viral spike protein. Several modes have been developed to deliver the viral $\mathrm{S}$ protein via vaccines in the bloodstream of individuals. These vaccines employ inactivated virion, nanoparticle fat encapsulated mRNA, viral-vectored vaccines, and DNA plasmid methods. Many of these vaccines have entered clinical trials and some have also reported the efficacy and immunogenicity of the vaccines.
These include AZD1222, BNT162b2, and mRNA-1273 vaccines [4].

\section{AZD1222 VACCINE}

AZD1222 vaccine was developed by University of Oxford and Vaccitech. The vaccine is composed of a weakened adenovirus (common cold virus), that infects chimpanzees, carrying the genetic machinery of SARS-CoV-2 spike protein. The viral chimpanzee vector used in vaccine is replication deficient. Vaccination induces the production of SARS-CoV-2 spike protein in the individual which primes the immune system developing immunological memory against SARS-CoV-2 upon future infection [5].

The AZD1222 efficacy proved to be $90 \%$ with one dosing regimen when given as a half dose $\left(\sim 2.5 \times 10^{10}\right.$ virus particles), followed by a full dose after one month, and $62 \%$ with second dosing regimen given as 2 -full doses $\left(\sim 10 \times 10^{10}\right.$ virus particles) with at least 2 -months interval via intramuscular injections [5]. The clinical trials of AZD1222 were ongoing across the world in Brazil, UK, US, Russia, South Africa, Kenya and Japan. Up to 60,000 participants, aged 18 years or over, belonging to various geographical, ethnic and racial groups are recruited in the trials. Positive high-end results were obtained from COV002 Phase II/III trial in the UK and COV003 Phase III trial in Brazil and were comparable to interim data results obtained previously from Phase I/II trial of the vaccine. Participants were randomized to receive AZD1222 or meningococcal comparator vaccine MenACWY, given one month apart as either one or two low ( 2.2 $\times 10^{10}$ virus particles) or standard ( 3.5-6.55 x10 virus particles) doses. Antibody responses, Tcell responses and neutralizing antibodies were seen in $100 \%$ of participants regardless of dosage or age. Mild local or 
systemic reactions were observed more often in younger adults ( $\geq 18-55$ years) as compared to older adults $(\geq 56$ years). These reactions include fatigue, temporary pain and tenderness at injection site, feverishness, myalgia and headache [5].

The vaccine can be handled, stored and transported at 2$8{ }^{\circ} \mathrm{C} / 36-46^{\circ} \mathrm{F}$ for at least 6 months and can be administered within the healthcare settings. The company, AstraZeneca is preparing regulatory submission to authorities for early or conditional approval. During the pandemic the access to AZD1222 will be at no-profit pledge. The global supply capacity of AZD1222 is secured towards approximately 3 billion doses on a rolling basis in 2021 for rapid availability in low-income countries [5].

\section{BNT162B2}

BNT162b2 is an ultra-low temperature formulated mRNA based COVID-19 vaccine developed by Pfizer and BioNTech. The observed efficacy of this vaccine is $95 \%$ in participants with or without prior SARS-CoV-2 infection after 7 days of second dose [6]. The efficacy of this vaccine is $94 \%$ in adults $>65$ years of age. The first dose of the vaccine is $30 \mu \mathrm{g}$ and provides fast and high protection against SARS-CoV-2 infection after 28 days of the second dose (given after 21 days). The efficacy of BNT162b2 is consistent across various racial, ethnical, geographical, and age groups. The vaccine does not cause serious safety issues except grade 3 severe events reported with a frequency $\geq 2 \%$. These include fatigue in $3.8 \%$ participants after the $1^{\text {st }}$ or $2^{\text {nd }}$ dose of vaccine and headache in $2 \%$ participants after second dose. These reactions were observed more often in younger participants as compared to older adults [6].

Pfizer and BioNTech enrolled 43,661 participants of age 18 years and older in the phase III clinical trial of the vaccine, out of which 41,135 participants also received second dose on November 13 of 2020 [9]. The trial also includes data of about 100 children aged 12 to 15 years and older adults aged 56 to 85 years. The vaccine can be stored for up to 6 months at ultra-low temperature. To maintain the viability of vaccine, cold-chain shipping infrastructure utilizing dry ice is employed by the companies to transport BNT162b2 vaccine candidate globally. The shippers and distribution hubs of the companies can store the vaccine for up to 15 days at $-70{ }^{\circ} \mathrm{C} \pm 10{ }^{\circ} \mathrm{C}$ by refilling with dry ice after 15 days. The temperature and location of each shipper is tracked by a GPS containing thermal sensor. After thawing, the recommended storage temperature of the vaccine vial is 2 to $8{ }^{\circ} \mathrm{C}$ for 5 days [9]. The companies were successful in supplying BNT162b2 vaccine candidate to greater than 150 sites of clinical trial across U.S., Latin America, South America, and Europe. The global supply capacity of Pfizer and BioNTech is expected to be approximately 50 million vaccine doses in 2020 and about 1.3 billion vaccine doses in 2021. The companies have yet to submit the safety data and efficacy of BNT162b2 vaccine candidate in a scientific journal for peer review [9].

\section{MRNA-1273}

mRNA-1273 is a vaccine being developed by the biotechnology company Moderna in collaboration with the National Institute of Allergy and Infectious Diseases. The proposed dosing regimen is 2 doses, $100 \mu \mathrm{g}$ each, administered 1 month apart. The efficiency of the vaccine proved to be $94 \%$ in clinical trials involving 30,000 participants [7]. The efficiency of the vaccine was consistent among individuals of various ethnicities, ages, demographics and geographics. Few short-lived side effects, including pain at injection site, fatigue, muscle aches, headache and lymph node swelling were widespread among the participants. However, no serious side-effects or allergic reactions have been observed in the participants. The recommended storage temperature of this vaccine is $-20{ }^{\circ} \mathrm{C}$ [7].

This vaccine contains RNA of SARS-CoV-2 protein in a fat bubble. When injected in an individual, this strand of RNA operates with the protein synthesis mechanism of the cell and make several copies of the spike protein of SARSCoV-2. The immune system of the individual forms neutralizing antibodies against the spike protein of SARSCoV-2. In a clinical trial involving 40 participants of age 56 years or above, the participants produced similar levels of neutralizing antibodies after the second vaccine shot as that of control group participants [8]. This vaccine candidate is likely to be produced at $\sim 6$ million doses to ship to 3285 locations in the $1^{\text {st }}$ week of approval [7].

TABLE I: COMPARATIVE ANALYSIS OF AZD1222, BNT162B2, AND MRNA-

\begin{tabular}{|c|c|c|c|c|}
\hline Vaccine & Developer & Efficacy & Doses & Storage \\
\hline AZD1222 & $\begin{array}{c}\text { University of } \\
\text { Oxford and } \\
\text { Vaccitech }\end{array}$ & $90 \%$ & $\begin{array}{l}1 \text { month apart. } \\
1^{\text {st }} \text { dose: } 2.5 \times 10^{10} \\
\text { virus particles } \\
2^{\text {nd }} \text { dose: } \\
5 \times 10^{10} \text { virus } \\
\text { particles }\end{array}$ & $\begin{array}{c}2-8^{\circ} \mathrm{C} \\
\left(36-46^{\circ} \mathrm{F}\right) \\
\text { For at least } \\
\text { six months }\end{array}$ \\
\hline BNT162b2 & $\begin{array}{l}\text { Pfizer and } \\
\text { BioNTech }\end{array}$ & $95 \%$ & $\begin{array}{c}30 \mu \mathrm{g}, 21 \text { days } \\
\text { apart }\end{array}$ & $\begin{array}{c}-70^{\circ} \mathrm{C} \pm 10^{\circ} \mathrm{C} \\
\left(-94^{\circ} \mathrm{F} \pm 50^{\circ} \mathrm{F}\right) \\
\mathrm{Up} \text { to } 15 \\
\text { days }\end{array}$ \\
\hline mRNA-1273 & $\begin{array}{l}\text { Modern and } \\
\text { the US } \\
\text { National } \\
\text { Institute of } \\
\text { Allergy and } \\
\text { Infectious } \\
\text { Diseases } \\
\end{array}$ & $94 \%$ & $\begin{array}{c}100 \mu \mathrm{g}, 1 \text { month } \\
\text { apart }\end{array}$ & $\begin{array}{l}-20^{\circ} \mathrm{C} \\
\left(-4^{\circ} \mathrm{F}\right) \\
\text { for up to six } \\
\text { months }\end{array}$ \\
\hline
\end{tabular}

\section{CONCLUSION}

The combined efforts of these companies will soon provide the world with an effective vaccine candidate. The administration of the authorized vaccine candidates in individuals will start soon after the approval of the vaccine by FDA. Until then, the use of face masks and social distancing is the best way to avoid the risk of infection. 


\section{REFERENCES}

[1] Dong, E., Du, H., \& Gardner, L. (2020). An interactive web-based dashboard to track COVID-19 in real time. The Lancet Infectious Diseases. https://doi.org/10.1016/S1473-3099(20)30120-1.

[2] World Health Organization (WHO, 2020). Weekly Epidemiological Update - 29 December 2020. Retrieved from https://www.who.int/publications/m/item/weekly-epidemiologicalupdate---29-december-2020.

[3] Walls, A. C., Fiala, B., Schäfer, A., Wrenn, S., Pham, M. N., Murphy, M., King, N. P. (2020). Elicitation of Potent Neutralizing Antibody Responses by Designed Protein Nanoparticle Vaccines for SARSCoV-2. Cell. https://doi.org/10.1016/j.cell.2020.10.043.

[4] Hassan, A. O., Kafai, N. M., Dmitriev, I. P., Fox, J. M., Smith, B. K., Harvey, I. B., Diamond, M. S. (2020). A Single-Dose Intranasal ChAd Vaccine Protects Upper and Lower Respiratory Tracts against SARSCoV-2. Cell. https://doi.org/10.1016/j.cell.2020.08.026.

[5] Kemp, A. (2020, November 23). AZD1222 vaccine met primary efficacy endpoint in preventing COVID-19. Retrieved December 13, 2020, from https://www.astrazeneca.com/media-centre/pressreleases/2020/azd1222hlr.html.

[6] Pfizer. (2020, November 18). Pfizer and BioNTech Conclude Phase 3 Study of COVID-19 Vaccine Candidate, Meeting All Primary Efficacy Endpoints. Retrieved from https://www.pfizer.com/news/pressrelease/press-release-detail/pfizer-and-biontech-conclude-phase-3study-covid-19-vaccine.

[7] Johnson, C. (2020, December 15). FDA review clears path for second coronavirus vaccine, this one developed by Moderna. Retrieved $\begin{array}{lll}\text { December } & 16, & 2020,\end{array}$ https://www.washingtonpost.com/health/2020/12/15/modernavaccine-found-safe-effective/.

[8] Anderson, E. J., Rouphael, N. G., Widge, A. T., Jackson, L. A., Roberts, P. C., Makhene, M., Beigel, J. H. (2020). Safety and Immunogenicity of SARS-CoV-2 mRNA-1273 Vaccine in Older Adults. New England Journal of Medicine. https://doi.org/10.1056/nejmoa2028436.

[9] Pfizer. (2020, November 20). Pfizer and BioNTech to Submit Emergency Use Authorization Request Today to the U.S. FDA for COVID-19 Vaccine. Retrieved from https://www.pfizer.com/news/press-release/press-release-detail/pfizerand-biontech-submit-emergency-use-authorization. 